\title{
A clinical audit and confidential enquiry of caesarean section indications at rural tertiary health care centre
}

\author{
Ketki N. Thool*, Shuchi M. Jain, Poonam V. Shivkumar, Manish A. Jain, Manjiri R. Podder
}

Department of Obstetrics and Gynecology, MGIMS, Sevagram, Wardha, Maharashtra, India

Received: 30 January 2017

Revised: 10 February 2017

Accepted: 02 March 2017

\author{
*Correspondence: \\ Dr. Ketki N. Thool, \\ E-mail: drketki10@gmail.com
}

Copyright: () the author(s), publisher and licensee Medip Academy. This is an open-access article distributed under the terms of the Creative Commons Attribution Non-Commercial License, which permits unrestricted non-commercial use, distribution, and reproduction in any medium, provided the original work is properly cited.

\begin{abstract}
Background: Worldwide CSR has been steadily increasing beyond recommended level of $15 \%$ by WHO. High CSR have been reported in developed and developing countries. Reasons for increase in CSR are not obvious and somewhat complex. Thus, present study was undertaken to analyze various indications for CS performed at rural tertiary health care centre Sewagram, M.S.

Methods: This was prospective study included all women who underwent CS from ${ }^{\text {st }}$ January 2015 till $30^{\text {th }}$ June 2016. Data was entered in MS excel sheet analyzed with percentage and chi square test using SPSS ver.17.

Results: CSR was $36.88 \%$ in present study. As per NICE guidelines CS were classified in four categories based on urgency, women were distributed in each category. Category I had $22.62 \%$, category II $-38.61 \%$, category III $-28.37 \%$ and Category IV - 10.40\% women. In CAT I common indication was foetal bradycardia (71.53\%). In CAT II CS, common indication was non reassuring foetal status (38.82\%). Breech presentation (14.74\%) and previous scar with doubtfull scar integrity (14.33) were next common indications. In CAT III (43.43\%), IV (41.13\%) previous LSCS with inadequate pelvis was the common indication. Confidential enquiry revealed that $26.17 \%(28 / 107), 20.3 \%$ (40/197), $23.17 \%,(35 / 151)$ and $8.3 \%$ (5/60) of CAT I , II, III and IV CS had questionable indications.

Conclusions: In this study, CSR was higher than WHO standard. Common indications in primipara was foetal distress while in multiparas primary indication previous LSCS
\end{abstract}

Keywords: Caesarean section, Category of CS, Confidential enquiry, Indications, Parity

\section{INTRODUCTION}

Caesarean section (CS) was brought in clinical practice as a life saving procedure both for mother and baby. Caesarean section (CS) is a surgical intervention which is carried out to assure safety of mother and child when vaginal delivery is difficult or when the doctors consider that the danger to the mother and baby would be greater with a vaginal delivery. As early as 1960, Munro Kerr wrote I fear that today more than ever before, there is a danger of abdominal delivery being regarded as the legitimate methods of dealing with each and every obstetrical abnormality.
Over the past 3 decades the caesarean section rate has risen dramatically. The rapid rise of CS rate all around the world has become a grievous public health issue. It is because several studies have showed that increased rate of caesarean section does not necessarily contribute to an improved and better maternal health and pregnancy outcome. WHO global survey on maternal and perinatal health in Latin America, in fact, unveiled that rate of caesarean delivery was positively associated with severe maternal and neonatal morbidity and mortality, even after adjustment of demographic characteristics, risk factors, type of institution and proportion of referrals. ${ }^{1}$ Also, unneeded caesareans beget higher expenditure at 
individual and national levels and have the potential to divert human and financial resources. In spite of these facts, CS is high and continues to hike in the developed world and in many developing countries. ${ }^{2}$

The consensus recommendation for optimal CS rate of 10$15 \%$ was made by WHO in 1985 which was revised in 1994. ${ }^{3}$ The guidelines published in 1997 by UNICEF, WHO and UNFPA states that proportion of Caesarean births should range between 5 to $15 \%$. The rate of Caesarean Sections below $5 \%$ seems to be associated with gaps in obstetric care leading to poor health outcomes for mothers and children, whereas rates over $15 \%$ don't seem to improve either maternal or infant health. However, increasing caesarean rates have raised the need to study its influencing factors. One hand there is tendency to liberalize the indication for caesarean section as per the demand by the clients on the other hand there is concern about the rising caesarean rate. So we audited the indications at our tertiary healthcare centre to find out commonest indication of $\mathrm{CS}$ in each category so as to reduce the increasing CSR.

\section{METHODS}

This audit of indications for caesarean section was conducted in Department of Obstetrics and Gynaecology, in a rural tertiary care institute located in central India, over a period of 18 months from January 2015 to June 2016, in pregnant women who reported to the hospital and underwent caesarean section. Data was retrieved from the files and filled into the data collection sheet.

These files were then traced during working hours in the labour ward and post-natal wards within 24 hours of the CS. The information sought in the files was from the doctor's notes. According to indications mentioned on files, caesarean sections were distributed into four categories according to NICE guidelines (2011) on basis of urgency as follows. ${ }^{4}$
- Immediate threat to life of woman or foetus (Category).

- Maternal or foetal compromise which is not immediately life threatening (Category II).

- No maternal or foetal compromise but needs early delivery (Category III)

- $\quad$ Delivery timed to suit woman or staff (Category IV).

Simultaneously a confidential enquiry was done for which predesigned form was filled from a health professional in labour room and anesthetist present during section for every 5th Caesarean section. Thus it was done in every 5th Women who underwent Caesarean section and was divided into respective Categories and results were analyzed. Confidential enquiry was done to identify various aspects of decision taking, validity of indication, $\mathrm{E}$ partography, labour monitoring and management, interpretation, intraoperative findings.

Statistical analysis of data was done by using descriptive and inferential statistics using chi-square test and software used in the analysis were SPSS 17.0 version, EPI-INFO 6.0 version and GraphPad Prism 6.0 and $\mathrm{p}<0.05$ is considered as level of significance $(\mathrm{p}<0.05)$. Clearance and approval from Institutional ethical and Research (Scientific) committee was obtained.

\section{RESULTS}

During audit period there were a total of 6908 deliveries, out of which 2548 were LSCS and 4360 were vaginal so the Caesarean section rate (CSR) in rural tertiary health care centre was $36.88 \%$.

All the 2548 women who underwent LSCS were audited for indications. As per NICE guidelines all CS were classified in four categorise on basis of urgency and women were distributed in each category. Category I had $22.62 \%$, category II had $38.61 \%$, category III had $28.37 \%$ and Category IV had $10.40 \%$ women.

Table 1: Indication in category I caesarean section and parity wise distribution.

\begin{tabular}{|c|c|c|c|c|c|c|}
\hline Indications & Nulliparous & $\%$ & Multiparous & $\%$ & Total & $\%$ \\
\hline Fetal bradycardia & 342 & 59.38 & 70 & 12.15 & 412 & 71.53 \\
\hline $\begin{array}{l}\text { Placenta previa with active } \\
\text { bleeding and in collapsed state }\end{array}$ & 21 & 3.65 & 18 & 3.13 & 39 & 6.77 \\
\hline $\begin{array}{l}\text { Placental abruptio with maternal } \\
\text { and foetal compromise }\end{array}$ & 44 & 7.64 & 24 & 4.17 & 68 & 11.81 \\
\hline Cord prolapse & 13 & 2.26 & 6 & 1.04 & 19 & 3.30 \\
\hline Obstructed labour & 14 & 2.43 & 8 & 1.39 & 22 & 3.82 \\
\hline $\begin{array}{l}\text { Previous lscs with eminent scar } \\
\text { rupture }\end{array}$ & 0 & 0.00 & 11 & 1.91 & 11 & 1.91 \\
\hline Retained $2^{\text {nd }}$ twin & 3 & 0.52 & 2 & 0.35 & 5 & 0.87 \\
\hline Total & 437 & 75.87 & 139 & 24.13 & 576 & 100.00 \\
\hline
\end{tabular}

Indication in Category I caesarean section and parity wise distribution 
Table 2: Indication in category II caesarean section and parity wise distribution.

\begin{tabular}{|lllllll|}
\hline Indications & Nulliparous & $\%$ & Multiparous & $\%$ & Total & $\%$ \\
\hline Non reassuring fetal status & 303 & 30.79 & 79 & 8.03 & 382 & 38.82 \\
\hline $\begin{array}{l}\text { Breech presentation in active phase of } \\
\text { labour }\end{array}$ & 117 & 11.89 & 28 & 2.85 & 145 & 14.74 \\
\hline $\begin{array}{l}\text { Previous LSCS with doubt full scar } \\
\text { integrity in active phase of labour }\end{array}$ & 0 & 0.00 & 141 & 14.33 & 141 & 14.33 \\
\hline $\begin{array}{l}\text { Abnormal presentation in active phase } \\
\text { of labour }\end{array}$ & 55 & 5.59 & 31 & 3.15 & 86 & 8.74 \\
\hline Deteriorating maternal condition & 43 & 4.37 & 37 & 3.76 & 80 & 8.13 \\
\hline Deep transverse arrest & 44 & 4.47 & 17 & 1.73 & 61 & 6.20 \\
\hline $\begin{array}{l}\text { Failure to progress in active phase of } \\
\text { labour }\end{array}$ & 54 & 5.49 & 11 & 1.12 & 65 & 6.61 \\
\hline Prolonged labour & 18 & 1.83 & 6 & 0.61 & 24 & 2.44 \\
\hline Total & 634 & 64.43 & 350 & 35.57 & 984 & 100.00 \\
\hline א2-value & $32.33, \mathrm{p}=0.0001$, Significant & & & \\
\hline
\end{tabular}

Indication in Category II caesarean section and parity wise distribution

Table 3: Indication in category III caesarean section and parity wise distribution

\begin{tabular}{|lllllll|}
\hline Indications & Nulliparous & $\%$ & Multiparous & $\%$ & Total & $\%$ \\
\hline Failure of induction & 152 & 21.02 & 25 & 3.46 & 177 & 24.48 \\
\hline $\begin{array}{l}\text { Previous LSCS with inadequate pelvis } \\
\text { in latent phase }\end{array}$ & 0 & 0.00 & 314 & 43.43 & 314 & 43.43 \\
\hline $\begin{array}{l}\text { Previous LSCS with fetoplacental } \\
\text { insufficiency in latent phase of labour }\end{array}$ & 0 & 0.00 & 113 & 15.63 & 113 & 15.63 \\
\hline Breech in latent phase of labour & 26 & 3.60 & 40 & 5.53 & 66 & 9.13 \\
\hline $\begin{array}{l}\text { Previous two LSCS in latent phase of } \\
\text { labour }\end{array}$ & 0 & 0.00 & 20 & 2.77 & 20 & 2.77 \\
\hline CPD in latent phase of labour & 23 & 3.18 & 5 & 0.69 & 28 & 3.87 \\
\hline Mother to fetus transmission & 0 & 0.00 & 5 & 0.69 & 5 & 0.69 \\
\hline Total & 204 & 28.22 & 519 & 71.78 & 723 & 100.00 \\
\hline N2-value & $72.18, \mathrm{p}=0.0001$, Significant & & & \\
\hline
\end{tabular}

Indication in Category III caesarean section and parity wise distribution

Table 4: Indication in category IV caesarean section and parity wise distribution.

\begin{tabular}{|lllllll|}
\hline Indications & Nulliparous & $\%$ & Multiparous & $\%$ & Total & $\%$ \\
\hline $\begin{array}{l}\text { Previous CS with inadequate } \\
\text { pelvis }\end{array}$ & 0 & 0.00 & 109 & 2.64 & 109 & 41.13 \\
$\begin{array}{l}\text { Breech presentation with } \\
\text { inadequate pelvis }\end{array}$ & 53 & 20 & 12 & 20.75 & 65 & 24.52 \\
\hline Placenta previum major degree & 3 & 8.68 & 10 & 16.98 & 13 & 4.90 \\
\hline Maternal request & 5 & 0.00 & 38 & 16.23 & 43 & 16.37 \\
\hline Contracted pelvis & 8 & 1.13 & 0 & 6.04 & 8 & 3.01 \\
\hline Abnormal Presentation & 3 & 1.89 & 7 & 7.92 & 10 & 3.77 \\
\hline Previous two LSCS & 0 & 3.02 & 11 & 5.28 & 11 & 4.1 \\
\hline Mother to foetus transmission & 3 & 1.13 & 0 & 2.64 & 3 & 1.1 \\
\hline Previous uterine incision & 1 & 0.37 & 2 & 0.75 & 3 & 1.1 \\
\hline Total & 76 & 28.67 & 189 & 71.32 & 265 & 100.00 \\
\hline N2-value & $44.60, \mathrm{p}=0.0001$, Significant & & & & \\
\hline
\end{tabular}

Indication in Category IV caesarean section and parity wise distribution

In category I most common indication was foetal bradycaria $(71.53 \%)$. Other indication was Placenta Previa with active bleeding and in collapsed state $(6.77 \%)$ placental abruptio with maternal and foetal compromise
$(11.81 \%)$ cord prolapse $(3.30 \%)$ obstructed labour previous LSCS with eminent scar rupture (1.91\%) Retained $2^{\text {nd }}$ twin $(0.87 \%)$. 
Table 5: Comparing indication for which patient was shifted for caesarean section and which was found uncertain by health personnel.

\begin{tabular}{|llll|lllllll|r|}
\hline Indications & CA T I & $\%$ & CA T II & $\%$ & CA T III & $\%$ & CA T IV & $\%$ & Total & $\%$ & \% \\
\hline Genuine & 79 & 73.83 & 157 & 79.70 & 116 & 76.82 & 55 & 91.66 & 407 & 79.02 \\
\hline Uncertain & 28 & 26.17 & 40 & 20.30 & 35 & 23.17 & 5 & 8.34 & 108 & 20.98 \\
\hline & 107 & 100 & 197 & 100 & 151 & 100 & 60 & 100 & 515 & 100 \\
\hline
\end{tabular}

Comparing indication for which patient was shifted for Caesarean section and which was found uncertain by health personnel

Table 6: Decision taken on investigations and not assessing clinically.

\begin{tabular}{|lllllllllll|}
\hline Indications & CAT I & $\%$ & CA T II & $\%$ & CAT III & $\%$ & CAT IV & $\%$ & Total & $\%$ \\
\hline Yes & 10 & 10.20 & 32 & 16.58 & 20 & 13.43 & 1 & 1.6 & 63 & 12.23 \\
\hline No & 97 & 90.65 & 165 & 83.75 & 131 & 86.75 & 59 & 98.33 & 452 & 87.76 \\
\hline & 107 & 100 & 197 & 100 & 151 & 100 & 60 & 100 & 515 & 100 \\
\hline
\end{tabular}

Decision Taken on investigations and not assessing clinically

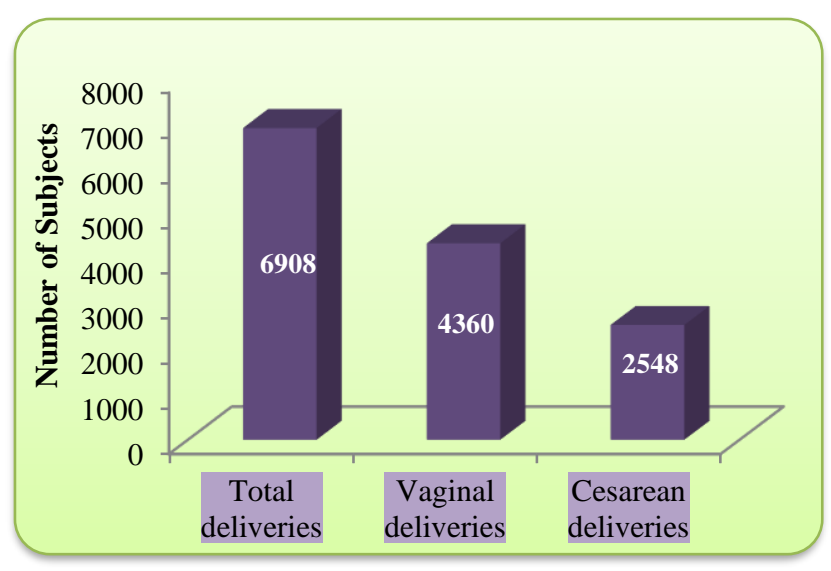

Figure 1: Caesarean section rate in tertiary health care centre $(\mathbf{3 6 . 8 8 \%})$.

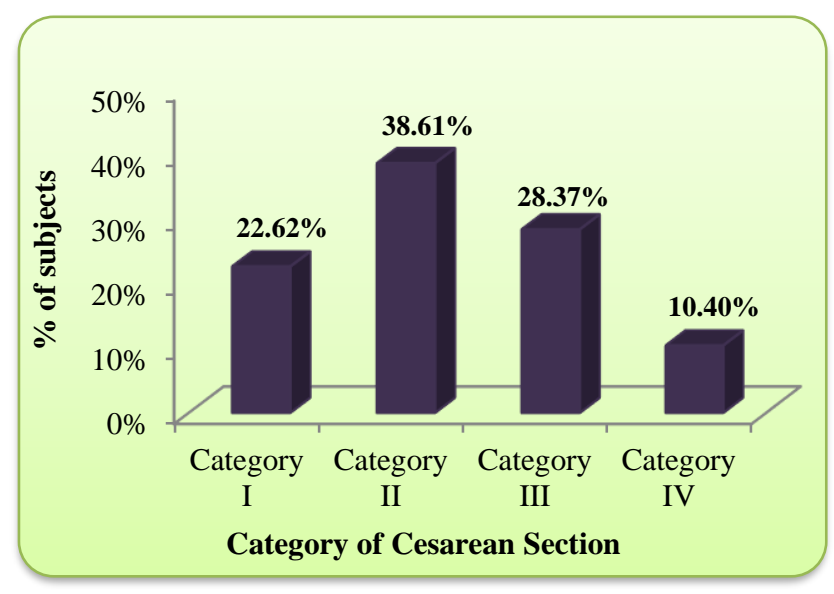

Figure 2: Categorisation of women according to NICE guidelines.

In category II CS, most common indication was non reassuring foetal status $(38.82 \%)$. Breech presentation $(14.74 \%)$ and previous scar with doubt full scar integrity (14.33) were the next common indications. In category III previous LSCS with inadequate pelvis was the common indication $(43.43 \%)$ followed by failure of indication (24.48\%) and previous LSCS with foetoplacental insufficiency (15.63\%). Most common indication in category IV was previous LSCS with inadequate pelvis $(41.13 \%)$, followed by breech presentation $(24.52 \%)$ and maternal request $(16.37 \%)$.

In Category I (75.50\%) and II (64.43\%) maximum women were nulliparous while in Category III (62.93\%) and IV $(65.66 \%)$ majority of women were were multiparous. This was because previous LSCS was one of the indication of Caesarean section done under category III and IV. Parity of women and categories of CS have statistical significance.

The Confidential Enquiry which was done revealed that amongst cat I CS $73.83 \%$ were shifted for Caesarean section with main indication were genuine while about $26.17 \%$ indications for CAT I CS were questionable .Similarly about $20.3 \%(40 / 197)$ cat II CS, $23.17 \%$ (35/151)cat III CS and $8.3 \%(5 / 60)$ Cat IV CS had indications which were questionable. According to health personnels indications like foetal distress, previous LSCS were deceptive ones. It was noted by anaesthetist that out of 197 emergency CS about $24.36 \%$ (48/197) were taken for foetal distress in which $9.89 \%$ neonates did not show any evidence of asphyxia at birth. In previous LSCS some patients could have been given a trial of VBAC.

\section{DISCUSSION}

The overall caesarean section rate (CSR) was computed as $36.88 \%$ in our study, which is more than $25.4 \%$ CSR reported in a study critical appraisal of Caesarean section rates at teaching hospitals in New Delhi 1998-1999 and $16 \%$ recorded in maternity hospital in Mumbai in 2001.,6 This is probably because our institute is a tertiary institute receiving referral from neighboring areas. However, present study figures were slightly comparable with another study in Madra in 2003. This is a hospital rate and 
not country rate, being a referral hospital had referrals from nearby hospitals and thereby increase in CSR. This rate is higher than the WHO recommended rates of between 10 and 15 percent. ${ }^{3}$ This rising rate of caeserean section have potential to divert human and financial resources from others, arguably higher priority Interventions. Around the world, the reported caesarean section rate was $21 \%$ in a teaching hospital in Pakistan in $2004,15 \%$ in France in 2001, 17.4\% in rural area in Australia in 2001, 30\% in Mexico in 2001, 26.9\% in teaching hospital in Nigeria and $19.5 \%$ in Iran in 1997. ${ }^{7-12}$

In present study Caesarean section is classified on basis of urgency as Category I, II, III and IV as in NICE guidelines .Women were categorized in four categorize and different indications in each category were studied.

Category I caesarean section was performed in situations that are extremely life-threatening for the mother or fetus or both. Main indications for this CS were foetal bradycardia (406), placenta previa (39), abruptio placentae (68), cord prolapsed (19), obstructed labour (22), previous LSCS with eminet scar rupture (11), retained $2^{\text {nd }}$ twin (5). Thus Foetal bradycardia was main indication for maximum number of CS 406 (70.49\%) in this category. Similar finding was seen in study done by Naeem $\mathrm{M}$ et al. ${ }^{13}$ However in an study done by Kathyryn and et al in Subafrican area obstructed labour was found out to be major indication in Caesarean section. ${ }^{14}$ Also population based study done by Barber et al observed that dystocia was the leading cause follow by foetal distress. ${ }^{15}$ In present study, only $22(3.8 \%)$ CS were done for obstructed labour. This is because continuous electronic fetal monitoring has been associated with greater likelihood of CS and the concept of e-Partography in labour rooms has enabled front-line providers to more rapidly assess and respond to labor complications and receive crucial guidance.

Category II CS is done when there is maternal or foetal complication which is not immediately life threatening. Various indications in category II were non reassuring foetal status $(38.82 \%)$, breech presentation (14.73\%), previous scar with doubtful scar integrity (14.33\%), abnormal presentation $(8.74 \%)$, deteriorating maternal condition $(8.13 \%)$ deep transverse arrest $(6.20 \%)$, failure to progress $(6.60 \%)$ and prolonged labour $(2.43 \%)$. Thus it was observed that most common indication for caesarean section in category II was non reassuring foetal status followed by breech presentation.

Category III CS was done when there is no maternal or feotal complications but early intervention is required. Indications in category III were Previous LSCS with inadequate pelvis (43.43\%), failure of induction (24.48\%), previous LSCS with fetoplacental insufficiency (15.63), breech presentation in latent phase of labour (9.13\%), CPD in latent phase of labour (3.87), previous 2 LSCS in latent phase of labour $(2.77 \%)$, Mother to foetus transmission $(0.69 \%)$.
Category IV CS was those which were planned and in present study it had $265(10.40 \%)$ caesarean sections. Various Indications were previous LSCS with inadequate pelvis $(41.13 \%)$, breech presentation $(24.52 \%)$, maternal request $(16.37 \%)$, contracted pelvis $(3.01 \%)$, abnormal presentation, previous 2 LSCS $(4.1 \%)$, and previous scarred uterus (1.1). Most common indication was previous LSCS with inadequate pelvis, followed by breech presentation .Similar findings have been noted in study carried out by Jackson and et al. ${ }^{16}$ In a study done at King Edward Memorial Hospital by Quinlivan Julie and etal reported that the common indication for elective Caesarean section was maternal choice because of refusal of women for trial of labour following previous LSCS. ${ }^{17}$

Multiparous women were more in category III and IV as previous LSCS was one of the indications of CS in this women. In category I and II also multiparous women had previous LSCS indication, thus study thus showed that previous caesarean section is an important factor and contributor in increasing caesarean section rate as out of total LSCS $41.32 \%$ women had at least 1 previous LSCS. This is similar with the findings of another study done by Gegory et al. ${ }^{18}$

Traditionally most of confidential enquiries till now (at both national and local level) are related to investigating deaths, to establish whether anything could have been done to prevent the deaths through better clinical care. Confidential enquiry into maternal and child health $(\mathrm{CEMACH})$ and national confidential enquiry into perioperative deaths (NCEPOD) are the recent national level confidential enquires conducted. Recently, it has also been introduced in LSCS audit in view of increasing CSR. In present audit we introduced confidential enquiry to detect areas of deficiency in and validity of indications for caeserean section. Confidential enquiry revealed $79.022 \%$ indications of LSCS as genuine and rest with questionable indications requiring further review to decrease CS.

\section{CONCLUSION}

This audit revealed that caesarean section rate was $36.80 \%$ in our medical college which is high according to WHO standard. According to NICE guidelines $60 \%$ of caeserean were done in emergency or urgency and rest were scheduled or elective. $53 \%$ CS were done in nulliparous women in whom main indication was foetal distress and $47 \%$ were done in multiparous women who had at least one previous LSCS.

The simultaneously confidential enquiry revealed that CSR can be decreased by taking following measures. The possible areas of improvement are, reviewing of indications like fetal bradycardia, non-reassuring fetal status, previous LSCS as some of them were questionable, involvement of senior staff and faculty in decision making and conduct of $\mathrm{CS}$, training junior faculty in conducting vaginal breech delivery, instrumental delivery and VBAC. 
Also at the present time, with a very few exceptions, most indications for caesarean section are relative. when indications for caesarean section are relative, the woman and her family should be closely involved with any decisions regarding mode of delivery.

Funding: No funding sources

Conflict of interest: None declared

Ethical approval: The study was approved by the Institutional Ethics Committee

\section{REFERENCES}

1. Betrán AP, Gulmezoglu AM, Robson M, Merialdi M, Souza JP, Wojdyla D et al. WHO global survey on maternal and perinatal health in latin america: classifying caesarean sections. Reproductive Health. 2009;6(1):18.

2. Lauer JA, Betrán AP. Decision aids for women with a previous caesarean section. BMJ. 2007;334(7607):1281-2.

3. Mukherjee S. Rising cesarean section rate. J Obstet Gynecol India. 2006;56(4):298-300.

4. Wee M, Brown H, Reynolds F. The National Institute of Clinical Excellence (NICE) guidelines for caesarean sections: implications for the anaesthetist. Int J Obst Anesthesia. 2005;14(2):147-58.

5. Kambo I, Bedi N, Dhillon BS, Saxena NC. A critical appraisal of cesarean section rates at teaching hospitals in India. Int $\mathrm{J}$ Gynecol Obst. 2002;79(2):151-8.

6. Mehta A, Apers L, Verstraelen H, Temmerman M. Trends in caesarean section rates at a maternity hospital in Mumbai, India. J Health Population Nutrition. 2001;19(4):306-12.

7. Khawaja N, Yousaf T, Tayyeb R. Analysis of caesarean delivery at a tertiary care hospital in Pakistan. J Obst Gynaecol. 2004;24(2):139-41.

8. David S, Mamelle N, Riviere O. Estimation of an expected caesarean section rate taking into account the case mix of a maternity hospital. Analysis from the AUDIPOG Sentinelle Network (France). Obstetricians of AUDIPOG. Association of Users of Computerised Files in Perinatalogy, Obstetrics and Gynaecology. BJOG. 2001;108(9):919-26.
9. Cameron B, Cameron S. Outcomes in rural obstetrics, Atherton Hospital 1991-2000. The Australian J Rural Health. 2001;9:39-42.

10. Perez GJ, Lopez MG, Pivaral C, Munoz A, Valle A. Caesarean sections in Mexico: are there too many? Health Policy Plan. 2001;16(1):62-7.

11. Ugwu EOV, Obioha KCE, Okezie OA, Ugwu AO. A five-year survey of caesarean delivery at a Nigerian tertiary hospital. Annals Med Health Sci Research. 2011;1(1):77-83.

12. Litorp H, Kidanto HL, Rööst M, Abeid M, Nyström L, Essén B. Maternal near-miss and death and their association with caesarean section complications: a cross-sectional study at a university hospital and a regional hospital in Tanzania. BMC Pregnancy Childbirth. 2014;14(1):1

13. Naeem M, Khan MZ, Abbas SH, Khan A, Adil M, Khan MU. Rate and indications of elective and emergency caesarean section; a study in a tertiary care hospital of Peshawar. JAMC. 2015;27(1):151-4.

14. Chu K, Cortier H, Maldonado F, Mashant T, Ford N, Trelles M. Cesarean section rates and indications in sub-Saharan Africa: a multi-country study from medecins sans frontieres. PloS one. 2012;7(9):e44484

15. Barber EL, Lundsberg L, Belanger K, Pettker CM, Funai EF, Illuzzi JL. Contributing indications to the rising cesarean delivery rate. Obstet Gynecol. 2011;118(1):29.

16. Jackson V, Irvine $\mathrm{N}$. The influence of maternal request on the elective caesarean section rate. J Obstet Gynaecol. 1998;18(2):115-9.

17. Quinlivan JA, Petersen RW, Nichols CN. Patient preference the leading indication for elective caesarean section in public patients-results of a 2-year prospective audit in a teaching hospital. Australian New Zealand J Obst Gynaecol. 1999;39(2):207-14.

18. Gregory KD, Henry OA, Gellens AJ, Hobel CJ, Platt LD. Repeat cesareans: how many are elective? Obst Gynecol. 1994;84(4):574-8.

Cite this article as: Thool KN, Jain SM, Shivkumar PV, Jain MA, Podder MR. A clinical audit and confidential enquiry of caesarean section indications at rural tertiary health care centre.Int J Reprod Contracept Obstet Gynecol 2017;6:1478-83. 